\title{
研究論文 天然ゴム一鋼板接着物の腐食劣化特性
}

(平成 5 年 7 月 21 日 受理)

\begin{abstract}
横井 宏* $\cdot$ 奥本 忠興* ·竹内 勝政*.今井 英幸*
要 旨 天然ゴム $(\mathrm{NR})$-鋼板接着物の腐食環境下での劣化による接着はく離を検討した．接着物は鋼 板-NR-鋼板の構成から成り，鋼板間を腐食試験前にあらかじめ $10 \%$ 伸長させて接着面にひずみを与え温水 浸せき，塩水浸せきおよび塩水噴霧の各試験条件下でゴムと鋼板との接着面の腐食による接着はく離，およ び, 鋼板の下地の表面処理 (グリットブラスト処理, リン酸亜鉛化成処理)の違いが腐食による直接はく離に 及ぼす影響を検討した．各腐食条件下でNR一鋼板(グリットブラスト処理)物を用いて接着はく離を調べた が，長時間の温水浸せきおよび塩水浸せき試験(2400時間)ではわずかに界面に接着はく離が見られる程度で あるが，塩水噴霧試験では腐食の接着界面への進行が速く，短時間(1440時間)で完全にはく離した。この現 象は温・塩水浸せき試験では腐食要素の酸素の供給に限りがあり, 塩水噴霧では酸素が豊富に供給されるた めと考学る. NR-鋼板接着物の鋼板の表面処理の違いについて, リン酸亜鉛化成処理接着物はグリットブ ラスト塩水噴霧試験条件下で, 約 6 倍の耐久寿命を示した。このようにリン酸亜鉛化成処理が耐腐食性に優 れるのは食塩水からの $\mathrm{Cl}^{-}$イオンに対して溶解し難いためと考兄る。また NR-鋼板接着物の接着端面から の腐食によるはく離機構について若干の考察を行った.
\end{abstract}

\section{1. 緒言}

北米, 北欧などの寒冷地域では自動車の安全走 行のため, 冬期に融雪塩を散布する。このため, 自動車の走行によって巻き上げられた融雪塩が車 体やゴム部品に付着 ·堆積し, 腐食を進行させ る1). 特に自動車のゴム部品の中でもブッシュ, エンジンマウント等の防振ゴム類は路面に近いこ とから, 走行時に道路の塩類を含む泥水にさらさ れやすく，塩水による耐腐食性を考虑する必要が ある.一般に防振ゴムは天然ゴム $(\mathrm{NR})$ と鋼板と の複合構成品であることから，腐食劣化に対して 鋼板の耐腐食性のみならずゴムと鋼板との接着は く離の防止が重要である。この NR-鋼板接着物 は未加硫ゴムと鋼板の被着体とを接着剂を介し, 加硫成形中にゴムの架橋反応と同時に一体化され る. 加硫接着物のゴムと接着剂層上塗りとは共架 橋し, 強固に化学結合していると言われてお $\eta^{2,3)}$, 腐食環境下でのはく離は起こりにくい. 一方, 接着剂層下塗り (プライマー) と鋼板との接 着は物理結合が主であり ${ }^{2)}$, その接着性は鋼板の

* 豊田合成株式会社材料技術部 ( $\mathbf{T} 492$ 稲沢市北島町 西の町30)
表面処理の状態に大きく依存する．このため鋼板 の表面処理すなわち接着下地処理は接着性および 腐食による接着面の耐久性能に対し, 重要であ る. 最近, 腐食性向上のため, 機械的処理のグリ ットブラスト処理から, 更に化学的処理の化成皮 膜処理を施す方法の採用が増えつつある ${ }^{4,5)}$. 従 来, これらの表面処理鋼板と天然ゴム $(\mathrm{NR})$ との 接着物に代表される防振ゴム類の耐久試験は製品 そのものを用いて温水浸せき, 塩水浸せき, およ び塩水噴霧試験により, あるいは実車耐久試験に より腐食による接着耐久性を評価してきた ${ }^{6,7)}$. このため NR-鋼板接着物の製品, あるいは実車 テストに替るテストピースでの簡便な試験評価法 が望まれている.

本報では NR-鋼板接着物の鋼板間をあらかじ め拡張してひずみを与え, 各種の腐食試験(温水 浸せき, 塩水浸せき, 塩水噴霧)を行い, 腐食条 件が接着界面のはく離に及ぼす影響および鋼板へ の表面処理 $($ グリットブラスト処理, リン酸亜鉛 化成処理)の違いが腐食による接着はく離を防ぐ 効果を検討した. また, 局部腐食電池の解釈に基 づき, 接着端面からの浸食による腐食はく離機構 について若千の考察を行った. 


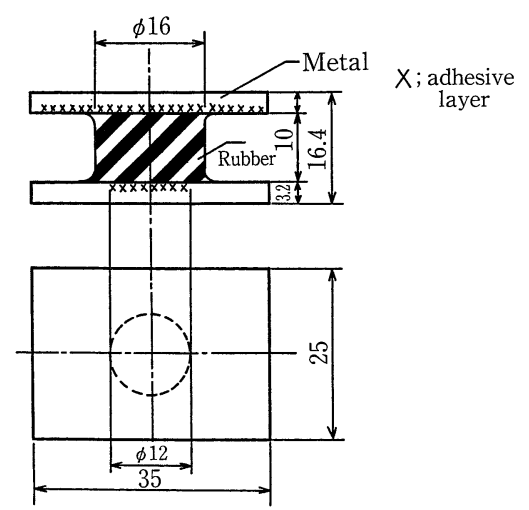

Fig. 1 Rough sketch of the newly designed test piece

\section{2. 実験}

\section{1 接着評価試験片の形状設計と作製}

防振ゴム類の実車テストの腐食劣化の代用とし てゴム一鋼板接着試験片を工夫した。その概要を Fig. 1 亿示す.

ゴム一鋼板接着試験片のはく離を促進するた め, 接着界面が露出し, かつ界面に引張応力(ひ ずみ)がかかるよらな形状を工夫した.ゴム一鋼 板接着試験片の接着強さ, 破壊状態の測定は JIS K6301に準じて行った.

まず表面処理を施した鋼板を 2 枚準備し， 1 枚 の鋼板には片面全面に，も51枚には片面中央部 $(12 \mathrm{~mm} \phi)$ のみに接着剤を塗布し, 乾燥を行っ た.この 2 枚の鋼板を金型にセットし, 未加硫コ ンパウンドを注入成形し, $150^{\circ} \mathrm{C} \times 30$ 分間ゴム材 料を加硫すると共にゴムと鋼板とを加硫接着させ た.このようにして成形した試験片は，一方の鋼 板は中央部のみ $(12 \mathrm{~mm} \phi)$ 接着したものとなる.

次に定伸長下での劣化状態を測定するため, 2 枚の鋼板間を $10 \%$ 伸長させて樹脂製スペーサーを 入れ，10\%定伸長状態に固定した。.Fig. 2 は試験 片を10\%伸長させた後スペーサーをセットした状 態を示す．鋼板片面は中央部 $(12 \mathrm{~mm} \phi)$ を接着し たことにより接着界面端部が $12 \mathrm{~mm} \phi$ 円周上に露 出しかつ界面には応力のかかった状態となる.

\section{2 試料}

2.2.1 ゴム材料 実験に供した原料ゴムは天 然ゴム（RSS No. 1)を用いた。 また, 配合剤のカ ーボンブラック，プロセスオイル，ステアリン

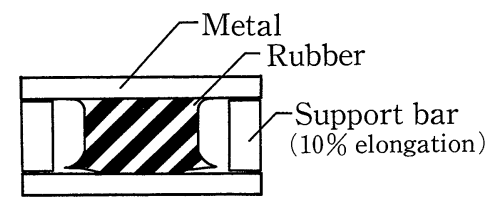

Fig. 2 Rough sketch of prepared test piece with $10 \%$ rubber elongation for corrosion

Table 1 Compounding recipes ${ }^{\text {a) }}$

\begin{tabular}{lr}
\hline \multicolumn{1}{c}{ Ingredients } & Phr \\
\hline Natural rubber(NR, RSS No.1) & 100 \\
MAF Black & 50 \\
Process oil (naphthenic) & 5 \\
Zinc oxide(ZnO) & 5 \\
Stearic acid & 1 \\
Wax (selested special wax, SUNNOC N) & 1 \\
Antioxidant (amine, NOCRAC810-NA) & 2 \\
Antioxidant (amine-ketone, NOCRAC224) & 2 \\
Curing agent (sulfenamide, NOCCELER CZ) & 1 \\
Sulphur & 2 \\
\hline
\end{tabular}

a; cured at $150^{\circ} \mathrm{C}$ for $30 \mathrm{~min}$

酸, 老化防止剤, 硫黄, 加硫促進剤等は市販品を 用いた。な拁加硫系はスルフェンアミド系の加硫 促進剂と硫黄との併用 ${ }^{15)}$ とした。 Table 1 に，加 硫ゴム配合を示す．未加硫ゴムコンパウンドは Table 1 に示した組成のゴム配合をバンバリーミ キサー(神戸製鋼所(侏) を用いて混練後, ロールで 分出しして作製した.

2.2.2 鋼板の表面処理 表面処理としては, 被着体の熱間圧延鋼板 (SPHC)の表面をあらす機 械的なグリットブラスト処理 (グリット粒径： JIS G5903の G20)と, グリットブラスト処理し たものを更に表面を無機の結晶で被覆するリン酸 塩化成処理の 2 種類を用いた. グリットブラスト 処理は接着下地処理としては一般的な方法であ り，投射材(グリット)を鋼板表面に投射し表面を 清浄・粗面化するものである6)。 また, リン酸塩 化成処理はリン酸亜鉛を主成分とする処理液中, $50^{\circ} \mathrm{C}$ で 6 分間処理し, リン酸亜鉛皮膜を形成さ せた。

2.2.3 鋼板への接着剂塗布 ゴムと鋼板の接 着に用いた接着剤はフェノール系下塗り加硫接着 剂(ケムロック205，ロード社製）打よび塩化ゴム 
系上塗り加硫接着剤(ケムロック220, ロード社 製）である ${ }^{3)}$. 下塗り，上塗りとも膜厚約 $15 \mu \mathrm{m}$ をスプレーで塗布し， $50^{\circ} \mathrm{C}$ 恒温槽中で 10 分乾燥 した.

\section{3 腐食試験}

2.3.1 温水浸せき試験 温水浸せき試験は, $10 \%$ 伸長した接着試験片を $60^{\circ} \mathrm{C}$ の温水 (イオン交 換水) 中に一定時間浸せきした後, 接着端面から はく離した部分の長さを測定した。

2.3.2 塩水浸せき試験 塩水浸せき試験は, $10 \%$ 伸長した接着試験片を $23^{\circ} \mathrm{C} ， 5 \%$ の塩化ナト リウム水溶液中に一定時間浸せきした後, 接着端 面からはく離した部分の長さを測定した.

2.3.3 塩水噴霧試験 塩水噴霧試験は温水試 験・塩水試験と同様に $10 \%$ 伸長した接着試験片を JIS Z2371に準じて, $35^{\circ} \mathrm{C}, 5 \%$ の塩化ナトリウム 水溶液噴霧下に一定時間セットした後, 腐食によ り接着端面からはく離した部分の長さを測定した。

\section{4 接着物の耐久度の測定}

2.4 .1 接着強さの測定 腐食試験前の接着試 験片を引張試験機 (テンシロン)にセットし, 試験 温度 $23^{\circ} \mathrm{C}$ 䨌囲気中, $25 \mathrm{~mm} / \mathrm{min}$ の引張速度で接 着強さを測定し, 破壊状態を目視で観察した。す た, 腐食試験後の接着強さおよび破壊状態も同様 な方法で測定した。

\section{4 .2 接着端面からのはく離幅の測定 $10 \%$} 伸長した接着試験片に対し一定時間劣化試験を行 い，外部ひずみと腐食劣化作用により接着界面 (鋼板と下塗り接着剤層の界面)が露出した部分の 長さの和を接着はく離幅とした. Fig. 3 に示され るように，接着試験片の接着界面の側面(1)と(2)に ゲージを入れて初期の長さおよび腐食劣化試験後 の長さを測定し，その差を A， B とすると接着は く離幅はその和で示す。

接着はく離幅 $=\mathrm{A}+\mathrm{B}(\mathrm{mm})$

$\mathrm{A}+\mathrm{B}$ が12 mm になると全面はく離を意味する。

\section{3. 結果と考察}

\section{1 接着物の初期接着強さ}

$\mathrm{NR}$-表面処理鋼板接着物の腐食劣化試験前の 接着強さと破壊状態を Table 2 に示す。グリット ブラスト処理鋼板括よびリン酸亜鉛化成処理鋼板 の接着物における腐食試験前の接着強さは8.8 $\mathrm{MPa}$ および8.4 MPa とほぼ同じ值を示した。ま たすべてがゴム部からの破断であった。これは， before corrosion test
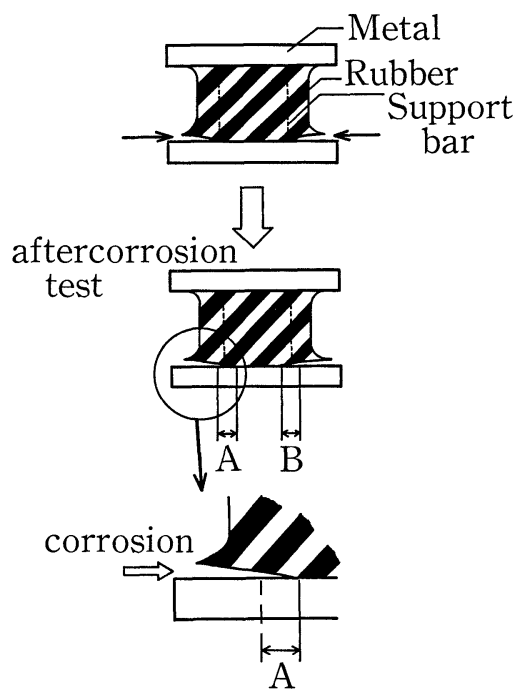

A, B: Peeling width

Fig. 3 Method for peel width measurement after corrosion test

Table 2 The adhesive strength and fracture pattern of destruction by tension

\begin{tabular}{l|l|l}
\hline Surface condition & $\begin{array}{l}\text { Adhesion } \\
\text { strength } \\
\text { before test } \\
(\mathrm{Mpa})\end{array}$ & Fracture pattern \\
\hline $\begin{array}{l}\text { Grit blasting } \\
\text { treatment } \\
\text { (TGE20) }\end{array}$ & 8.8 & $\begin{array}{l}\text { Destruction in } \\
\text { rubber layer }\end{array}$ \\
\hline $\begin{array}{l}\text { Phosphating } \\
\text { treatment }\end{array}$ & 8.4 & $\begin{array}{l}\text { Destruction in } \\
\text { rubber layer }\end{array}$ \\
\hline
\end{tabular}

$\mathrm{NR}$-鋼板接着物の破断に至るまでの接着強度は ゴム自身の破断強さであり、ゴム・鋼板間の接着 はゴム破断以上の強固な接着力を示している. 次 に腐食環境下での接着面の腐食劣化とともにゴム と鋼板との接着状態を観察した.

\section{2 腐食劣化条件の影響}

本実験に供した NRーグリットブラスト処理鋼 板の接着物のテストピースはTable 1 の材料コン パウンドを作製後, 加硫成形して得た。このテス トピースを治具により $10 \%$ 伸長させた状態 (Fig. 2)で温水浸せき, 塩水浸せきおよび塩水噴霧試験 


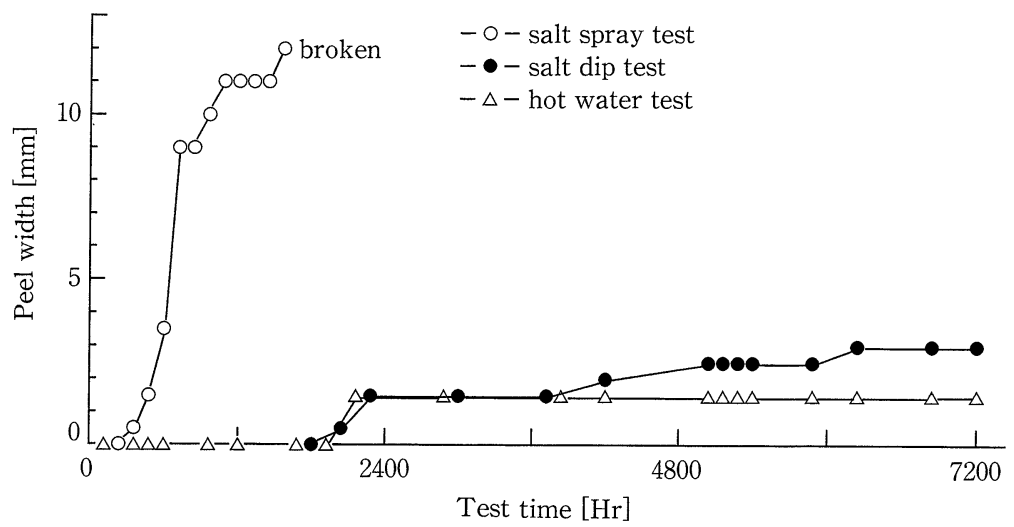

Fig. 4 Relations between corrosion time and peel width in the case of grit blasting treatment metal plates

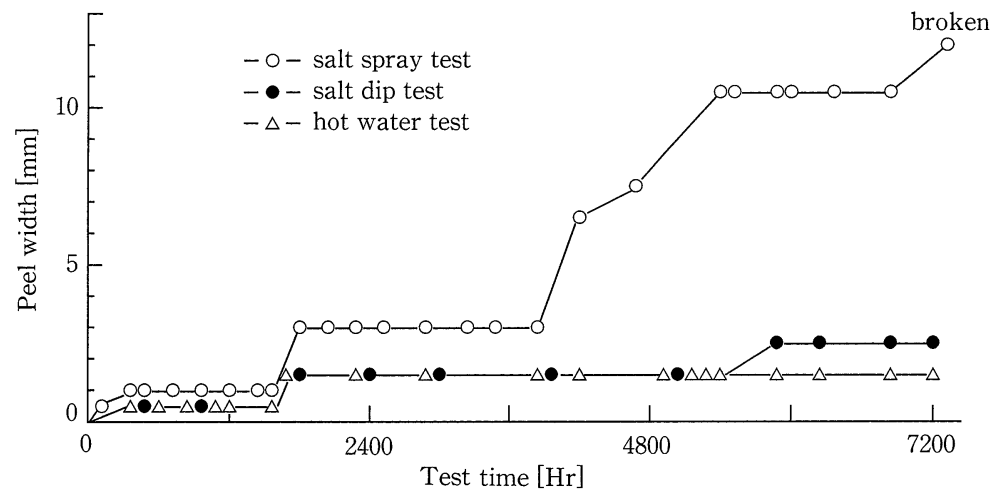

Fig. 5 Relations between corrosion time and peel with phosphating treatment metal plates

を行った．Fig. 4 はNRーグリットブラスト処理 鋼板接着物を用いた場合の各腐食条件下での腐食 時間と接着面のはく離幅との関係を示す。また, Fig. 5 は同時に NR-リン酸亜鉛化成処理鋼板を 用いたときの各腐食条件下での接着面のはく離幅 を示す。

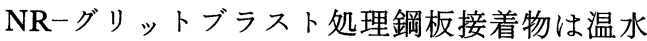
浸せき試験において2400時間でわずかにはく離が 見られるが，これ以後はほとんどはく離の進行は 見られなかった。同じ試料を用いた塩水浸せき試 験において2400時間でわずかにはく離が見られ， 時間とともにわずかであるが更にはく離が進行す る.また，鋼板の露出部は塩水浸せきの方が腐食 は進行していたが，端面の接着はく離を観察する とほとんど差は見られなかった，一方，塩水噴霧 試験においては徐々にはく離幅は広がり，1,440
時間(60日間)経過後全面にはく離を生じた。この とき露出した鋼板部は腐食し, 赤さびが発生して いた，接着はく離は一般に接着端面から徐々に中 心に向かって起こる。すなわち, 塩水噴霧試験は 腐食による進行が速く, 端面に接着はく離を起こ すが，長時間の塩水浸せきでは接着界面の腐食の 進行はほとんど見られなかった，温・塩水浸せき 試験でグリットブラスト処理鋼板接着物の耐久性 が優れるのは, 鋼板の表面処理状態がち密であ り, 接着剤の下塗りとの密着性が優れるためであ $3^{8)}$. グリットブラストの投射材が微粒子(グリ ット粒径：JIS の G20) であるため, 処理鋼板の 表面粗度が非常にち密になり, 表面の凹凸に接着 剤(プライマー)が流入し，アンカー効果が得ら れ，せん断などによる脆性破壊が防止されるため と考える ${ }^{9)}$. たた, 温水浸せき拈よび塩水浸せき 
Table 3 Strength at break and fracture pattern by tension after corrosion test

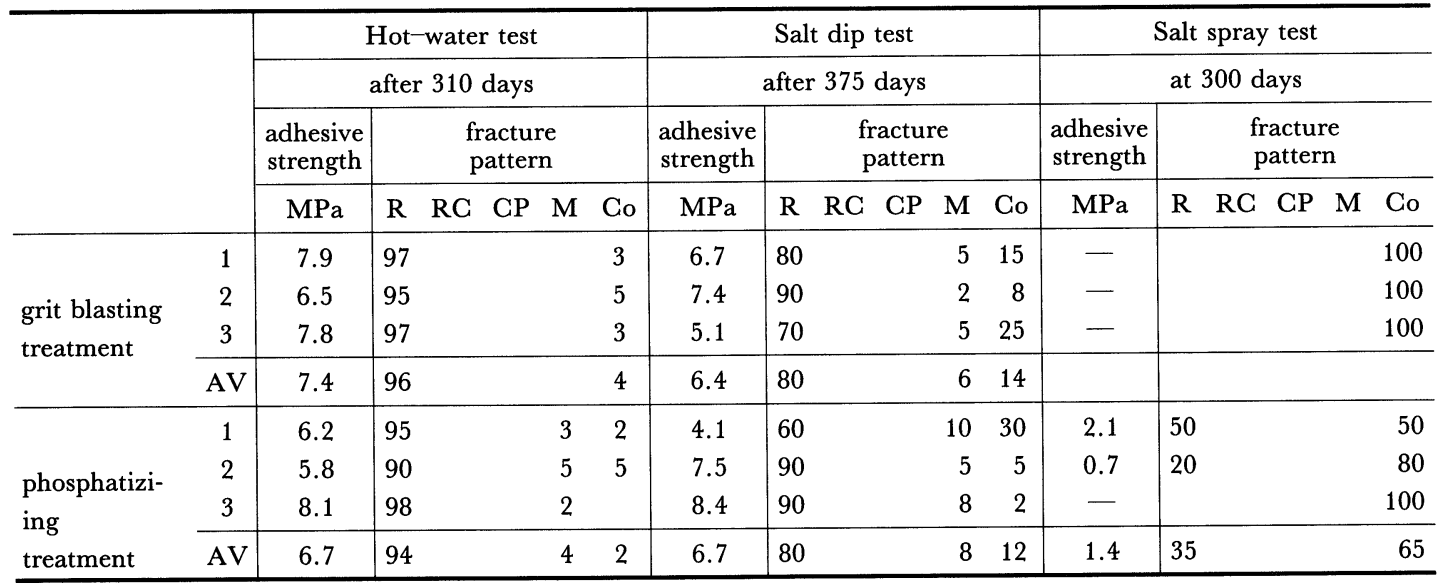

fracture pattern ; $R$ : fracture in rubber layer

$\mathrm{RC}$ : fracture between rubber and cover coat

CP : fracture between cover coat and primer coat

$\mathrm{M}:$ fracture in metal layer

Co : corrosion part appeared

は湿潤条件下での接着性を評価しており, 接着層 を透過する水分が少ないことを示している。すな わち，NR一鋼板接着物は腐食因子の水分の透過 はほとんどないものと考える。

次に腐食試験経過途中での腐食状態扣よび接着 強さを観察した。腐食時間が温水浸せき7,440時 間(310日), 塩水浸せき 9,000 時間(375日)および 塩水噴霧7,200時間 (300日) 経過後の接着強さと破 壞状態の観察結果を Table 3 に示す. 腐食に関し て温水浸せきでは腐食 $(\mathrm{Co})$ は少なかったが，塩 水浸せきでは腐食は多くなり, 塩水噴霧ではほと

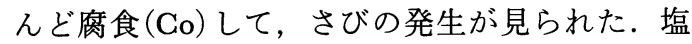
水噴霧試験は腐食が速いのは腐食因子の活性な酸 素の供給が豊富であり，腐食部での酸素濃度が高 いことにあると考える。いずれの腐食条件におい ても接着強さは腐食による接着面積が減少するこ とにより低下するものの, 破壊面を観察するとす べてゴム破壊を示した。腐食環境下では腐食端面 からの接着はく離は進行して接着強さは低下する が，ゴムと鋼板間の接着は強固に維持されてお り，強制的に破断してもゴム部からの破断を示 す。このことは腐食の進行は接着層の端面から進 行しているといえる. また, 塩水噴霧試験は他の 試験条件よりも腐食の進行が速く，かつ赤さびが 観察された。
このように塩水浸せきと塩水噴霧との腐食試験 に㧊いて，大きな差異を生じた。一般に金属の腐 食は酸素, 水, イオンの腐食反応剤が存在すると きに起こる ${ }^{10)}$. 塩水噴霧試験では酸素が豊富に供 給されるため，腐食は速く進行するが，塩水浸せ きは塩水中の溶存酸素のみで供給は乏しく, かつ 腐食先端で酸素が消費されると空気中からの酸素 の溶解の過程を経るため, 腐食の進行が遅れる.

このため塩水噴霧試験が他の浸せき試験よりも腐 食の進行は速いものとなる.すなわち塩水浸せき と塩水噴霧との差異は, 腐食反応剂である供給さ れた酸素の濃度にあると考兄る。

\section{3 化成処理の腐食への影響}

鋼板へのグリットブラスト処理あよび化成処理 は，いずれも鋼板とゴムとの密着力を強固にする ため施される．また，後者は裸の鋼板の防食性の 向上に有効である. 化成処理は無機質の不動態膜 を形成し，特にリン酸亜鉛化成処理がよく用いら れる(10),11)。ここでの鋼板へのリン酸亜鉛化成処 理はあらかじめ, グリットブラスト処理した上に 施されており，ゴムと鋼板との接着物の接着剂層 の下塗りと鋼板の間にリン酸亜鉛皮膜層が形成さ れている．塩水噴霧試験条件でグリットブラスト 処理およびリン酸亜鉛化成処理鋼板接着物の試験 時間とはく離幅との関係を Fig. 6 亿示す。グラ 


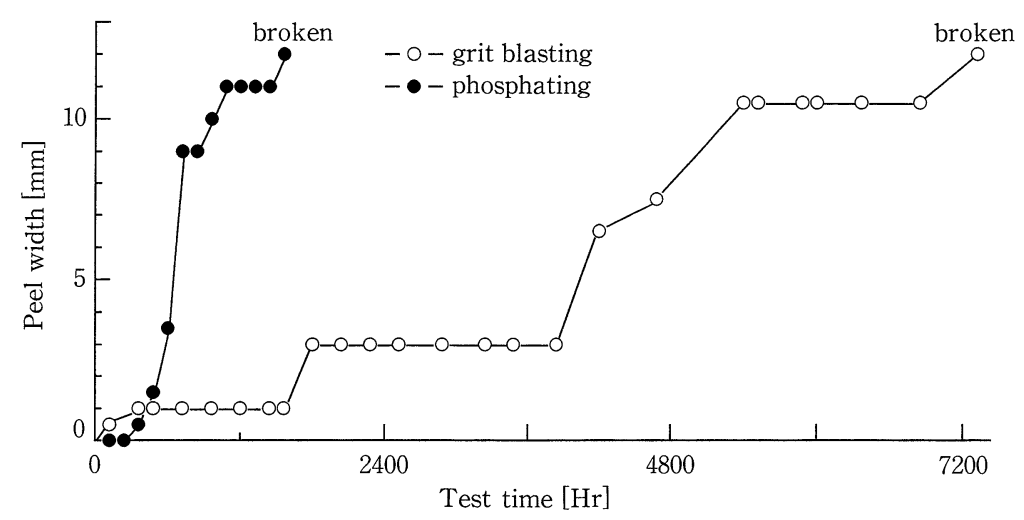

Fig. 6 Relations between salt dip test time and peel width by use of grit blasting and phosphating samples

ットブラスト処理鋼板接着物は 1,200 時間過ぎた 点で完全にはく離するのに対して, リン酸亜鉛化 成処理は7200時間で完全にはく離する．すなわち 後者は腐食による接着はく離に対しては約 6 倍の 耐久性がある。リン酸亜鉛化成処理は電気化学的 腐食反応であり鋼板の表面性状の影響を受けて形 成される．すなわち，鋼板をグリットブラスト処 理後, ち密なりン酸亜鉛皮膜を形成し, 鋼板と強 固に結合している11). このため食塩水からの $\mathrm{Cl}^{-}$ イオンに溶出し難いし, かつ水や酸素の腐食試剤 が鋼板までに通過し難しいため，化成皮膜が $\mathrm{Cl}^{-}$ イオンに溶出されるのに時間がかかる。 また, 接 着剤層下の化成皮膜が $\mathrm{Cl}^{-}$イオンに溶出し難く, 侵食し難いためと考学る。

\section{4 腐食による界面はく離機構}

鋼板の腐食は鉄と腐食反応剤(水, 酸素, イオ ン) との電気化学反応である ${ }^{13)}$. 外部電池を使う わけではないので電池の構成要件を満たすだけ腐 食が進行することになる，すなわち，鉄の溶解反 応 (アノード) と還元反応 (カソード) とからなる腐 食電池の挙動である.この反応は素地の鉄とは異 なった腐食物を生成する。一般に金属の腐食は酸 化皮膜を形成して, 次の攻撃を防ぐが，鉄の場合 は皮膜堆積層が粗(ポーラス)なため, 腐食反応試 剂の水を吸収し, 酸素を透過して, 続いて腐食電 池の反応が進み，次々と腐食が進行する.

本研究に用いた NR-鋼板接着物の腐食の電気 化学的解釈による界面はく離の過程を Fig. 7 に 示す。

1）腐食試験前の試料は $10 \%$ の伸長をかけてセッ (a) Initial State

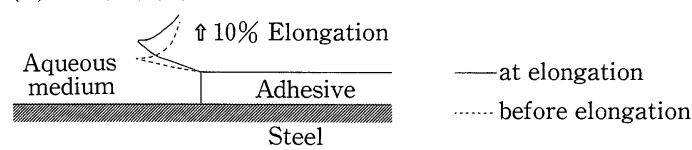

(b)

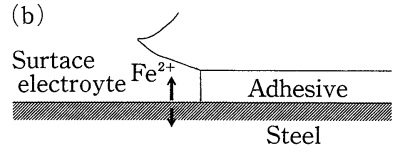

Initial Anode Reaction $\mathrm{Fe} \rightarrow \mathrm{Fe}^{2+}+2 \mathrm{e}^{-}$

(c)

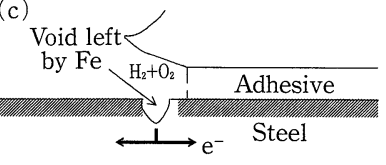

Free Electrons Migrate in Metal

(d)

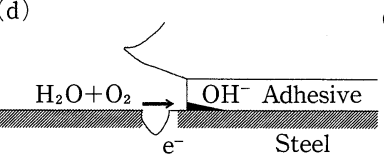

Cathode Reaction $2 \mathrm{e}^{-}+1 / 2 \mathrm{O}_{2}+\mathrm{H}_{2} \mathrm{O} \rightarrow 2 \mathrm{OH}^{-}$

(e)

Precipitation of Rust as $\mathrm{Fe}(\mathrm{OH})_{2}$,

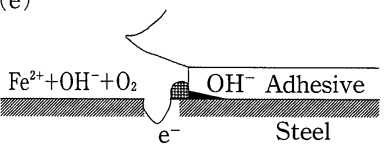

$\mathrm{Fe}_{2} \mathrm{O}_{3} \cdot \mathrm{H}_{2} \mathrm{O}$ or $\mathrm{Fe}_{3} \mathrm{O}_{4}$

(f)

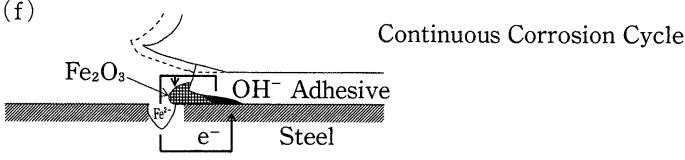

Fig. 7 Schematic corrosion mechanism at surface on the grit blasted steel 


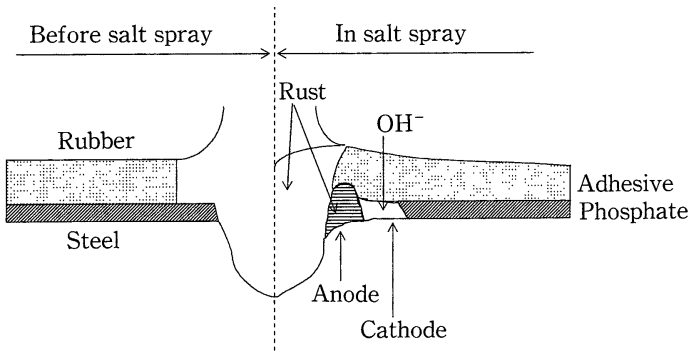

Fig. 8 Schematic cross section of coated phosphated steel during salt spray corrosion

トし, 接着界面は常に応力がかかった状態で腐食 環境下に暴される(Fig. 7 (a))。本報では接着界 面で腐食によるはく離の端面からの距離を計測す る.

2）腐食は裸の鋼板の鉄が電解質溶液にさらさ れ, 溶解して, 電子 $\left(\mathrm{e}^{-}\right)$を生成することから始 まる.すなわち，アノードとなる (Fig. 7(b)).

3）電子は金属中を移動し，腐食の先端でカソー ド反応をとる位置に平衡に保ち, 局部電池を形成 する. このとき, 端面から水分や酸素が透過して いる(Fig. $7(\mathrm{c})$ ).

4）この電子は水や酸素と反応し，ヒドロキシイ オンを接着端面の境界で形成し，カソード反応を とる(Fig. $7(\mathrm{~d})$ ).

$$
2 \mathrm{e}^{-}+1 / 2 \mathrm{O}_{2}+\mathrm{H}_{2} \mathrm{O} \longrightarrow 2 \mathrm{OH}^{-}
$$

5）電解質でイオンが泳動し，アノードで生成し た $\mathrm{Fe}^{2+}$ とカソードで生成した $\mathrm{OH}^{-}$とが反応す る.

$$
\mathrm{Fe}^{2+}+2 \mathrm{OH}^{-} \longrightarrow \mathrm{Fe}(\mathrm{OH})_{2}
$$

あるいは $\mathrm{Fe}^{2+}$ が水溶液中の酸素と反応する.

$$
\begin{aligned}
2 \mathrm{Fe}^{2+}+1 / 2 \mathrm{O}_{2}+\mathrm{H}_{2} \mathrm{O} \longrightarrow 2 \mathrm{Fe}^{3+}+2 \mathrm{OH}^{-} & \longrightarrow 2 \mathrm{Fe}(\mathrm{OH})_{3} \\
2 \mathrm{Fe}^{3+}+6 \mathrm{OH}^{-} & \longrightarrow \mathrm{Fe}_{2} \mathrm{O}_{3}+\mathrm{H}_{2} \mathrm{O}
\end{aligned}
$$

これらの化学反応を通して腐食生成物が沈澱ある いは表面に堆積する(Fig. 7(e)).

6）結局，腐食の進行は更に鉄が溶解しながら消 耗し, 腐食穴(ボイド)は広がり, 電子の移動が繰 り返され再度ヒドロキシイオンを生成し, 継続す る. NR-鋼板接着物の端面からのはく離は初期 の腐食段階で腐食が端面の接着剤皮膜下に進行し て，かつ端面に引張応力もかかった状態にあるこ とから界面はく離を生ずる(Fig. 7(f)).

促進腐食試験の塩水噴霧の環境下では電解質溶

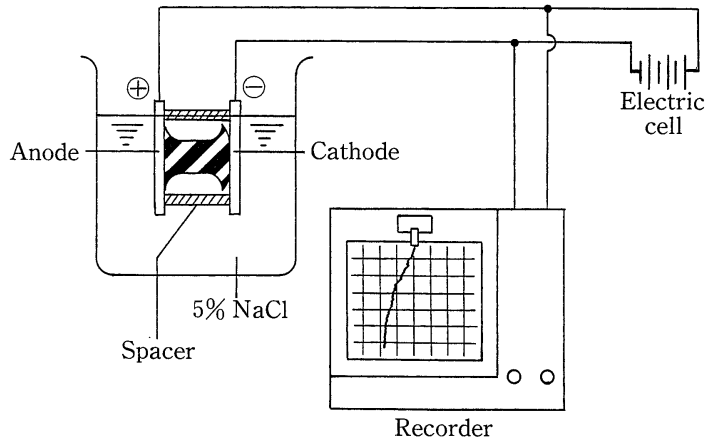

Fig. 9 Test method of electrochemical corrosion test in $5 \% \mathrm{NaCl}$ solution for $10 \%$ elongation test piece

Table 4 Results of electrochemical corrosion test in $5 \% \mathrm{NaCl}$ solution

\begin{tabular}{l|c|c|c}
\hline \multicolumn{2}{c|}{} & \multicolumn{2}{c}{ Broken time[Hrs] } \\
\cline { 3 - 4 } \multicolumn{2}{c|}{} & Grit blasting & Phosphating \\
\hline $\begin{array}{l}\text { Current in } \\
\text { electro- } \\
\text { chemical } \\
\text { corrosion test }\end{array}$ & $0.5 \mathrm{~A}$ & 1.2 & 6.7 \\
\cline { 2 - 4 } & $1.0 \mathrm{~A}$ & 0.5 & 3.0 \\
\cline { 2 - 4 } & $1.5 \mathrm{~A}$ & 0.3 & 1.8 \\
\hline
\end{tabular}

液存在下で豊富な酸素の供給が腐食を促進してい る.

1）まず食塩は解離して, $\mathrm{NaCl} \rightarrow \mathrm{Na}^{+}+\mathrm{Cl}^{-}$になり, $\mathrm{Na}^{+}$はカソード部, $\mathrm{Cl}^{-}$はアノード部に泳動する.

2）アノード部では $\mathrm{Cl}^{-}$が鋼板の鉄の溶解によ る $\mathrm{Fe}^{2+}$ と反応して腐食が進行する.

$$
\begin{aligned}
& \mathrm{Fe} \longrightarrow \mathrm{Fe}^{2+}+2 \mathrm{e}^{-}: \text {鉄の溶解 } \\
& \mathrm{Fe}^{2+}+2 \mathrm{Cl}^{-} \longrightarrow \mathrm{FeCl}_{2} \text { : 塩化第 } 1 \text { 鉄の生成 } \\
& \mathrm{FeCl}_{2}+2 \mathrm{H}_{2} \mathrm{O} \longrightarrow \mathrm{Fe}(\mathrm{OH})_{2}+2 \mathrm{HCl}
\end{aligned}
$$

: 酸性化

$$
\mathrm{Fe}(\mathrm{OH})_{2}+1 / 2 \mathrm{H}_{2} \mathrm{O}+1 / 4 \mathrm{O}_{2} \longrightarrow \mathrm{Fe}(\mathrm{OH})_{3}
$$
: 赤さびの発生

3）カソード部では腐食先端あるいは接着界面で アルカリ性化が起こる.

$$
\begin{aligned}
& \mathrm{H}_{2} \mathrm{O}+1 / 2 \mathrm{O}_{2}+2 \mathrm{e}^{-} \longrightarrow 2 \mathrm{OH}^{-} \\
& : \text {アルカリ性化 } \\
& \mathrm{Na}^{+}+\mathrm{OH}^{-} \longrightarrow \mathrm{NaOH}: \text { アルカリ性化 }
\end{aligned}
$$

塩水噴霧が腐食を促進するのは, 酸素が豊富に供 給されるためアノードでのさびの発生拈よびカy ードでのアルカリ性化を加速することにある.

リン酸塩化成処理鋼板の耐腐食性が優れている 
のは, リン酸亜鉛皮膜は $\mathrm{Zn}_{3}\left(\mathrm{PO}_{4}\right)_{2} \cdot 4 \mathrm{H}_{2} \mathrm{O}$ 又は $\mathrm{Zn}_{2} \mathrm{Fe}\left(\mathrm{PO}_{4}\right)_{2} \cdot 4 \mathrm{H}_{2} \mathrm{O}$ の微細な結晶構造をとり, 化学的に非常に安定で, 耐酸性 $\left(\mathrm{Cl}^{-}\right)$に優れるた めである. 本報のリン酸亜鉛化成処理は特に鋼板 をグリットブラストによりメカノケミカル的に活 性化して，ち密なリン酸亜鉛の結晶皮膜を形成し ているため効果がある12)。これらの特徵から，ま ず腐食促進初期段階で鋼板上に処理したりン酸亜 鉛皮膜が $\mathrm{Cl}^{-}$イオンなどに溶解しにくいため, 鉄が溶出するアノードの生成が遅れる，またキズ があった場合, 腐食が進行する過程で Fig. 8 に 示すように, 腐食の先端のカソードで酸素や水が 透過しにくいため, 強了ルカリ下での湿潤接着性 に優れ，カソード反応が起こりにくいことにあ

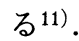

塩水噴霧試験での接着はく離が局部電池反応か ら，カソード面のアルカリ性化 $\left(\mathrm{OH}^{-}\right)$による腐 食に基づくことを確認するために，NR-鋼板接 着物を塩水に浸せきし, 外部電池により, 接着物 の一方の鋼板表面をすべてカソード面として接着 界面はく離を見る方法を筆者らは試みた。この方 法の概要を Fig. 9 に示す。テストピースを用い て試験した結果を Table 4 に示す．わずかな電流 (外部電池) で非常に短時間ではく離を生じ，かつ はく離はカソード側でのみ生じた。一方，アッー ド側ははく離を生じなかったが，裸の鋼板部は鉄 が溶解し減少していた。カソード側でのみはく離 を生じたのは外部電池により, 豊富な $\mathrm{e}^{-}$が供給 され，水溶液中の水，酸素と反応して $\mathrm{OH}^{-}$を生 成し, 次にアソードからの多量に溶解した $\mathrm{Fe}^{2+}$ と反応して腐食物 $\left(\mathrm{Fe}(\mathrm{OH})_{2}\right)$ を生成・堆積しは く離につながったと考劣る。すなわち，Fig. 8 の メカニズムに示すように，腐食の先端がカソード 反応を伴い, 接着端面から順次, はく離してく る.リン酸亜鉛皮膜が耐久性に優れるのは前出の ごとく $\mathrm{Cl}^{-}$イオン溶解し難いためと考える.

\section{4. まと め}

両面を鋼板でサンドイッチされた NR加硫接 着物を用い鋼板面を10\%拡張させて接着面にひず
みを与えて，腐食環境下での接着端からのはく離 に対する耐久性を評価した。グリットブラスト処 理鋼板接着物を用いた長時間の温水浸せきでは腐 食による接着界面はく離はわずかな進行にとどま り, 塩水噴霧試験では時間の経過とともに接着端 面から徐々にはく離が進行し，700時間で界面は く離を生じた．塩水噴霧試験で腐食によるはく離 が速く進行するのは，噴霧により空気中の酸素が 豊富に供給され腐食部の酸素濃度が高いためと考 える．また，塩水噴霧でリン酸㩊鉛化成処理が機 械的なグリットブラスト処理より耐腐食性に優れ るのは塩水からの腐食反応により生成した $\mathrm{Cl}^{-}$ イオンに対して溶解し難く，また鋼板とはち密な 結晶で強固に密着しているため接着剂層と鋼板間 での腐食の進行は遅れ，接着はく離に対する耐久 性に優れたものと考える，更に接着端面からの接 着はく離は局部電池反応に基づく鋼板部の腐食部 の先端で腐食反応剤(水, 酸素, イオン)によるカ ソード反応による $\mathrm{OH}^{-}$の生成とそれに続く腐食 物の生成の過程が接着端面の鋼板とゴムの接着剤 層間で徐々に進行し，ゴム面に引張ひずみがかか った状態ではがれたと考える。

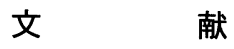

1）長岡哲夫 : 塗装工学, 22, 333 (1987)

2）芝崎一郎：日ゴム協誌，39，870（1966）

3）岩澤登代司：日本接着協会誌, 16, 467 (1980)

4) 大藪権昭 : 塗装工学, 23, 283 (1988)

5）沼田充弘, 鬼沢浩二, 嶋田巧三, 石田 亘, 伊藤 和俊：自動車技術，39，340（1985）

6）三吉康彦：実務表面技術，32, 319 (1985)

7）外川靖人：塗装工学, 22, 353 (1987)

8）三沢俊平：日本金属学会会報，24，201（1985）

9）中尾 宗：日本接着協会誌，15，425（1979）

10）市田敏郎：塗装工学, 19, 93 (1984)

11) Van Ooij, W. J.: Surface and Interface Analysis, 9, 367 (1986)

12）松島安信, 藤崎亜起男: 塗装工学, 20, 318 (1985)

13）佐藤忠明，西本忠史，木莫英雄：金属表面処理技 術, 35, 134 (1984)

14）佐藤 靖 : 塗装工学, 22, 373 (1987)

15） NOC 技術ノ一ト：日ゴム協誌，41，834（1968） 


\title{
DURABILITY OF NATURAL RUBBER TO METAL ADHESIVES UNDER CORROSIVE ENVIRONMENT
}

\author{
Hiroshi YOKOI, Tadaoki OKUMOTO, Katsumasa TAKEUCHI, Hideyuki IMAI (Toyoda \\ Gosei Co., Itd; 30 Nishinomachi, Kitajima-cho. Inazawa, Aichi, Japan, 492)
}

A rubber vibration insulator was composed of rubber and steel metal fittings which are prepared by rubber to metal bonding under vulcanization. To evaluate the performance of the adherends under a corrosive environment, the adherends were elongated by inserting the spacer in the gap between the steel plates before corrosion test. The corrosion tests such as hot water dip test, salt solution dip test and salt spray test were carried out and bonding degradation factors in corrosive environment were studied to find diffetences in degradation between these tests. Resulting from these tests difference in the failure of bonding between hot water test and salt dip test was not found, while the salt spray test was found to be the most severe. The failure of bonding in the salt spray test was acceralated by test time and the bonding layer was completely destroyed for 1400 hours. The reason is supposed to be due to the effect of oxygen in the salt spray test The phosphated treatment of metal surfaces was superior to grit blasting treatment for adhesion performance in corrosive environment. It is concluded that failure of bonding in corrosive environment is attributable to the reaction of corrosive elements $\left(\mathrm{H}_{2} \mathrm{O}, \mathrm{O}_{2}, \mathrm{e}^{-}\right)$on the surface of steel plates in the presence of oxygen in the air and $\mathrm{NaCl}$.

(Receivea on July 21, 1993) 